\title{
"WE ARE JOINED TOGETHER TEMPORARILY" THE TRAGIC MULATTO, FUSION MONSTER IN LEE FROST'S THE THING WITH TWO HEADS
}

\author{
Justin Ponder \\ Marian University
}

Jack Moss (Rosey Grier) lies in a hospital bed, sedated and recovering from grueling surgery. His drowsy eyes flutter open and fall upon his reflection in the mirror. The black man discovers the head of a white man, Dr. Maxwell Kirshner (Ray Milland), attached to his shoulder. His terrified hands poke and prod the growth until Kirshner growls, "Take your hands off of me!" Moss demands an explanation, asking the head where the rest of its body is before the doctor simply explains, "We are joined together temporarily." So begins the turning point of Lee Frost's The Thing with Two Heads, the 1972 blaxploitation horror film featuring a monster with two heads: one black, one white.

The film arrives at this point after Dr. Kirshner, a racist surgeon, begins battling terminal cancer. With only a few weeks to live, he devises a plan to transplant his head onto another body, but the only available one belongs to Jack Moss, a black convict on death row. After doctors successfully graft Kirshner's head onto Moss, these drastically different personalities drag their shared anatomy in opposite directions. While in control of the body, Moss escapes from prison and tries to prove his innocence. While Dr. Kirshner has control, he tries to turn himself into the police and remove Moss's head. This two-headed man fuses separate persons but also segregated races in a kind of conjoined twin mulatto.

Despite, or perhaps precisely because of, this campy premise, the film offers serious consideration of the relationship between conjoined twins and mulattoes. Throughout history, both have been considered monstrous. The former has challenged notions of individuality while the latter has challenged ideas about race, and analyzing the similarities between conjoined twin and mulatto monster discourses can reveal much about American assumptions about normative anatomy as well as normative monoraciality. Despite its flaws, The Thing with Two Heads occupies a special place in American discourse because it articulates the ways in which conjoined twins and mulattoes resemble each other as monsters that defy notions of personal and racial selfhood in the United States. 


\section{CONTEXT}

Before exploring how this film fits into the context of tragic mulatto discourse, it would be valuable to first explore the history of this trope. The tragic mulatto stereotype has largely been a literary one with novels written by all kinds of writers-African Americans, whites, anti-racists, and bigots, various thinkers using the multiracial character to either defend or challenge racism. To a certain extent, in American literature and scholarship, a type of subgenre has emerged, a sort of tragic mulatto literature that, regardless of an author's racial identity or political purposes, focuses on black-white biracial protagonists.

From Charles W. Chesnutt's The House Behind the Cedars (1900) to James Weldon Johnson's The Autobiography of an Ex-Colored Man (1912) to Nella Larsen's Passing (1929), there has emerged a kind of canon of tragic mulatto literature, and in scholarly works from Judith Berzon's Neither White Nor Black to Werner Sollors' Neither Black Nor White Yet Both, certain texts have garnered attention while others fell by the wayside. Regarding tragic mulatto literature, the most respected and analyzed works have been by African American writers from either the Reconstruction Era or the Harlem Renaissance writing for overtly political reasons, using the melodramatic plights of biracial characters to condemn racism. What has emerged as the informal catalog worth scholarly attention is also dominated by relatively realistic story worlds: political subjects in American society grappling with racial constructs and the confines of white supremacy. These sentimental works might stretch the bounds of plausibility, but they rarely bend the limits of reality itself. They may feature exaggerated versions of human characters and sensational depictions of multiracial life-extraordinary circumstances that do not reflect the struggles of real multiracial Americans-but they do not venture into the intentionally bizarre.

With the relative realism of tragic mulatto literature, any horror text dealing with multiraciality becomes extraordinary. An essential characteristic of the horror genre that distinguishes it from all others is that it takes possibility to fantastic lengths. The rules of physical existence no longer apply because the dead can walk, humans become wolves, and ghosts haunt houses. Such works seem to employ these supernatural elements to terrify audiences, using the impossible to horrify viewers and readers, but to belong to the horror genre it is not enough for a text to merely frighten audiences. Simple sight gags, jumping out of the bushes, or a screeching bus can do that. To go beyond temporary fright to paralyzing horror, texts must present more than a physical threat; they must present what Noël Carroll calls a "cognitive threat" that compromises more than a person's sense of physical safety (34). They must undermine a person's sense of the world, everything she assumes to be true, 
the very foundation of her individual knowledge as well as her culture's conceptual foundations. In this regard, horror, by its very character, must stretch reality, must explore the ridiculous to achieve its purposes. To be horror, these texts must not represent reality as it is; they must consider what it could be.

Therefore, horror, to a certain extent, does not have to back up its underlying premises with realistic credibility. Its fictions are speculative, dealing with possibilities rather than plausibilities, and, for this reason, they are especially ripe for theoretical examination. Horror scholars have continually shown how this "ridiculous" genre exposes society's deepest anxieties, values, and fears more than "serious" genres. For example, Philip Brophy's notion of "horrality" noted how these films combined horror and humor as a fruitful site for theoretical exploration precisely because they did not attempt to be realistic. Robin Wood has argued that horror films expose "the return of the repressed," unveiling the horrors a society would like to disavow. Like a patient of psychoanalysis lying on a couch may provide "truer" information by relaying her unconscious dreams than by articulating her conscious thoughts, American culture may reveal itself more honestly through incredible genres like horror than more serious ones like literature.

In the case of tragic mulatto fiction, scholars that analyze "serious" works could benefit from making room for more ridiculous ones. Beyond the pursuits of authors during the Reconstruction Era or the Harlem Renaissance, horror films of the 1970s have the relative luxury of theoretical speculation. While writers like Chesnutt, Johnson, and Larsen wrote with a greater sense of urgency for audiences that required realistic settings, characters, and plots, the horror directors of the 1970s wrote with a greater sense of speculation for audiences that were willing to suspend their disbelief to an unparalleled extent.

Therefore, horror texts, by the very aspirations of their character, enjoy a degree of freedom other kinds do not. Those works that consider biracial issues have the opportunity to explore the contradictions of American racial discourse in ways other mulatto literature cannot, because, freed from the confines of political expediency or literary plausibility, the horror genre can investigate the possibilities of race in ways no other genre can. At the same time, precisely due to their ridiculousness, because of their silly plots and laughable premises, essentially because their surrealism of ten reveals things about reality, these texts may also jokingly expose the truest aspects of American racism.

To see the degree to which humorously absurd horror films may reveal seriously penetrating truths about race relations in the United States, we need to look no further than The Thing with Two Heads. A movie about a black convict and white racist sharing a body certainly fits 
the bill of a ludicrous text, but to consider the possible significance of this film, in addition to understanding its position in tragic mulatto literature, we must first examine its position in the subgenre of blaxploitation horror film. Largely produced between 1969 and 1976, blaxploitation films targeted African American audiences to an unprecedented extent. Notable films include hits such as Sweet Sweetback's Baadasssss Song (Van Peebles 1971), Shaft (Parks 1971), and Superfly (Parks 1972). ${ }^{1}$ Most of these movies dealt with urban strife, poverty, and crime, but, in 1972, the genre expanded beyond the confines of gritty realism with William Crain's Blacula. Rather than focus on cops, drug dealers, and pimps, this film rewrote the Dracula tale by placing an African American vampire (William Marshall) in contemporary Los Angeles. Following Blacula's success, a string of "African-Americanized" horror films were released including Blackenstein (Levey 1973), Abby (Girdler 1974), and Dr. Black, Mr. Hyde (Crain 1976).

As part of the exploitation industry, these films were produced cheaply and, without the hope of gaining wider viewership, confronted unpopular issues. As part of the blaxploitation industry targeted mostly for African American audiences, these films explored racial issues that films made for whites of ten avoided. As horror films, they inserted unrealistic elements into otherwise realistic narratives, exploring black reality in ways other films had not. In "Blaxploitation Horror Films: Generic Reappropriation or Reinscription?" Harry M. Benshoff notes the ways in which films from this genre used the monster as "an allegory for the historical experience of African Americans" (38). Throughout horror films, monstrosity often erupts as a result of fusing disparate elements. Many Blaxploitation horror films used their monsters as an opportunity to "play out interesting variations on W.E.B. DuBois's concept of 'twoness' in the African American psyche" (39). Blacula, Blackenstein, and Dr. Black all suffered the internal conflict of monsters that haunted other corners of horror film, but unlike them their struggles were also racial ones as they grappled to unite multiple physical forms into a single monstrous body but also multiple racial identities into a single racial body. In this regard, blaxploitation horror films enjoyed a perfect storm of material conditions and genre expectations that permitted them to consider racial issues in ways other texts could not.

American International Pictures was at the forefront of such films. Created in 1956, this production company focused on low-budget, independent double features for teenagers. Early on, the studio churned out drag racing and beach movies, but, by the $60 \mathrm{~s}$, launched into acclaim

1 For an interesting source on the ways in which other Blaxploitation films alluded to biracial issues, see Gregory T. Carter's "From Blaxploitation to Mixploitation: Mixed-Race, Male Leads and Changing Black Identities." 
with the Roger Corman and Vincent Price remakes of Edgar Allan Poe stories. In the 1970s, they moved into blaxploitation films like The Mack (Campus 1973), Black Caesar (Cohen 1973), and Foxy Brown (Hill 1974). In 1972, they combined their two most lucrative genres of horror and blaxploitation with Blacula. Feeding off this success, AIP sought to make another blaxploitation horror hit. Sticking to the Blacula success formula, executives did not seek to create a second film from scratch as much as put a black face on a previous horror hit. To do this, the production company turned to their previous release, The Incredible TwoHeaded Transplant, a 1971 horror film about a mad scientist who transplants the head of a serial killer onto the body of a mentally disabled man. While this film explored the struggle between a murderer and an innocent trapped in one body, producers simply racialized this conflict, placing a black man and a white man in a single body, and The Thing with Two Heads was born.

At the helm of this project was Lee Frost, a veteran of exploitation cinema. From nudies to mondo shock documentaries, westerns to blaxploitation, he had nearly a decade of experience and more than twenty films under his belt before 1972. Throughout his genre-bending career, he remained interested in pushing the envelope while challenging audiences, using campiness to make bitter social messages more palatable. For the role of the parasitic head, AIP sought Ray Milland. The Welsh actor began his career under contract with Paramount in 1934 where he played sophisticates, aristocrats, and Brits in romantic comedies. By the 70s he experienced a minor revival playing racist patriarchs in blaxploitation horror films, symbolically carrying with him a kind of elderly, Hollywood-approved, bigot-playing whiteness to his performance in the film. For its star, AIP found quite the opposite in Rosey Grier. The football star enjoyed a distinguished career on the field as part of the L.A. Rams" "Fearsome Foursome." Off the field, he acted on television and film with a recurring role in "Daniel Boone" (1964) and "The Rosey Grier Show" (1969). By the early 70's, he had joined the ranks of a band of athlete-actors brandishing a bold new brand of African American machismo. With the likes of Fred Williamson, Jim Brown, and Jim Kelly, Grier had come to symbolize authoritative, cool, self-possessed blackness. His persona both fed and was fed by the growing Black Power Movement that rejected "safe black" personalities like Sidney Poitier and Nat King Cole. Instead, he rose with a crop that embodied a "buck" counter-stereotype, an emerging symbol in Afrocentric discourse. In these ways, even before a single frame of the film begins to role, these different media personalities bring racial meanings to the film. 
FILM

In The Thing with Two Heads, Dr. Kirshner, is a brilliant surgeon suffering terminal cancer. The transplant expert denies his fate, spending years developing experiments by which he may survive. After months of research, he develops a process for a head transplant. First, he grafts the head of one gorilla onto the body of another. Second, he allows the gorilla to live as a two-headed animal. Third, after the transplanted head acclimates itself to the host body, Dr. Kirshner removes the original head. Successfully completing this surgery on lab animals, he seeks to overcome his deadly disease by transplanting his head onto someone else's body. Doctors from his transplant institute issue calls for test subjects. In cryptic proposals, they only state that they seek healthy bodies of willing participants who should not expect to survive the procedure. Dr. Kirshner's situation worsens. Growing more and more desperate, he lashes out at colleagues and alienates friends, retreating into his experiments and growing bigotry. He hires Dr. Fred Williams (Don Marshall) to take over the institute after his death, but when the surgeon shows up for his first day and is African American, Dr. Kirshner sends him packing, claiming the position is no longer available.

The doctor's health quickly takes a turn for the worst and he loses consciousness. As Kirshner clings to life, his associates intensify their search for a body donor, but the only one available belongs to Moss, a black convict on death row. Knowing the racist surgeon would find it revolting to have his head grafted onto a black body, the doctors consider passing on the option, but, without any other prospects, they decide to perform the surgery. When Kirshner awakes from the successful surgery, he is pleased, but once he discovers his head attached to a black body, he is infuriated. On the other hand, Moss donated his body thinking it would go to a noble cause, but when he awakes to find he was tricked into eventually dying for a cantankerous bigot, he is enraged. $\mathrm{He}$ escapes Kirshner's underground laboratory, overpowers the police, and takes Dr. Williams hostage.

From then on, Moss and Kirshner drag their shared body in opposing directions. While in control of this body, Moss evades the police in hopes of proving his innocence and rescinding his death sentence. To avoid the police, he launches into high speed car chases and shoot-outs. In perhaps the film's most hilarious digression, he even flees in a nearly twenty-minute motorcycle race that pits his dirt bike against dozens of squad cars. In typical blaxploitation fashion, the cunning black lead evades the racist officers. Through masterful jumps, turns, and tricks, he sends the bewildered police into one crash after another, until he both escapes and destroys the entire fleet of police cars in the process. 
Once free, he tracks down his girlfriend, Lila, played by Chelsea Brown. She provides the two-headed monster and Dr. Williams with food and shelter while they plan their next steps. As she tries to come to terms with the second head grafted upon her lover's body, Dr. Williams grapples with a decision of his own. Dr. Kirshner tries to persuade him that Moss is a convicted killer who should die. He bribes Dr. Williams, promising to turn the Kirshner Institute over to him if he removes Moss' head. Conversely, Moss insists upon his innocence, telling the transplant surgeon to remove Dr. Kirshner's head so he can have a chance at freedom.

In the end, Dr. Williams becomes convinced of Moss' innocence and agrees to surgically remove Dr. Kirshner from his body. The trio break into a medical supply warehouse for necessary tools when Kirshner takes control of the body, beats Williams unconscious, and calls his surgeon friends to remove Moss' head. In the middle of the surgery, however, Williams rushes in and stops the doctors at gunpoint, snatching the scalpel away, saying, "You wouldn't want to do that, doctor. You'd be killing an innocent man." In the end, Kirshner awakes, a disembodied head sustained by a heart-lung machine, groaning for another body as Moss, Lila, and Dr. Williams drive down the street, singing "Oh Happy Day."

\section{Fusion MONSTERS}

With this plot, what kind of monster does The Thing with Two Heads present? Scholarship on monsters has produced its own kind of taxonomy, lists of different types of monsters with their particular and defining characteristics. The best known and most influential is that posited by Carroll in The Philosophy of Horror. In this Aristotelian catalog of monster types, he suggests a two-headed monster would best fit into the category of a fusion monster. To understand what a fusion monster means, one must first consider the construction of cultural knowledge. To form conceptual frameworks, cultures create dualisms, dividing the world into mutually exclusive halves. A culture's understanding operates insofar as its people are able to neatly split existence dualistically. According to Carroll, fusion monsters are those that combine opposing attributes into a single body and horrify because they violate dichotomies (43). In a society that divides nature between land animals and aquatic creatures, amphibians become fusion monsters. In another that splits the world between flyers and walkers, people may shriek at the sight of flamingoes. In any case, fusion monsters blur the neat lines societies use to both separate and see the world.

Fusion monsters undermine dualisms in three ways. First, fusion monsters violate physical difference. Fusion monsters physically com- 
bine multiple bodies into one, transgressing biological boundaries that supposedly separate individuals (45). For example, Frankenstein's monster contains an arm from one body, a leg from another, and a head from a third. Such creatures horrify because they undermine a culture's physical sense of selfhood. Within a culture that assumes boundary is flesh, that biology is who we are and clearly delineates us from others, fusion monsters horrify because they take the bodies of many and fuse them into the body of one.

In addition to combining multiple physical entities into a single body, fusion monsters also combine multiple psychologies into one. Carroll claims Frankenstein's creation is a fusion figure because the film "presents him as if he had different brains imposed upon him" (44). Here, the fusion monster transgresses psychological divisions to join multiple psyches in one flesh.

A third characteristic of fusion monsters is that they unite multiple souls. According to Carroll, fusion figures require the "ontological categorical ingredients that go into making monsters" (48). For example, he references possession stories like The Exorcist where one body houses numerous souls (44). In this film, Regan is horrific because she vomits sludge, contorts her body, and stabs herself, but also because she compromises Western beliefs in a personal soul. Does she have one soul? If she can be possessed, has she lost that soul? To a certain extent, fusion monsters horrify because they force us to face these difficult and confusing questions that complicate our assumptions about ontological identity.

\section{Conjoined Twin Fusion Monsters}

Before considering how the fusion monster in The Thing with Two Heads exemplifies these characteristics, it would be valuable to explore him as a conjoined twin. By simply grafting the head of the doctor on the head of the convict, the film conjures up and exploits the deep-seated anxieties that conjoined twins have inspired for centuries. To a certain extent, the film borrows from the intellectual history of conjoined twins to inherit the horror they might induce. Like the siblings joined at birth struggle to make sense of their shared body, Moss and Dr. Kirshner battle while they are temporarily joined together. To consider the cultural meanings of the monstrous "thing with two heads," we should first consider the social significance often linked to its semiotic relative, conjoined twins.

History contains extensive discussions on the nature of conjoined twins as scientists, psychologists, and theologians grapple with the difficulties that the mere existence of these beings pose to cultural assumptions, assumptions fundamental to people's sense of self, individuality, and identity. By challenging these assumptions, conjoined twins pose a 
cognitive threat that has horrified philosophers, doctors, and priests as each field in its own way has suggested they are fusion monsters.

First, conjoined twins exemplify fusion monsters because they combine multiple bodies into one. The body supposedly marks the boundaries of personhood, and flesh marks the limits of who one is. "I" ends with my skin, but what about conjoined twins who share flesh? Even as far back as ancient Greece, thinkers struggled with this issue, experimenting with different limit cases, considering what organ one had to share with a twin before they were no longer an individual. From Aristotie to Ambroise Paré, they claimed twins could share hips, livers, or heads and still be two individuals, but if they shared a heart they became one person (Paré 14). Seventeenth-century thinkers, however, claimed conjoined twins could share all matter of limbs, spines, and organs, but could only be considered two people if they had two heads (63). While these arguments had their differences, they shared a fascination with the limits of personhood, the physical boundaries where one self ended and another began.

Second, conjoined twins have horrified people because they fuse multiple psychologies into a single body. Most discourse on conjoined twins fixates on their personality differences. For example, Chang and Eng, the world's most famous conjoined twins, were anatomically joined but psychologically divided. The former drank heavily and fought bitterly while the latter was quiet and long-suffering. Conflicts between these opposed personalities grew so fierce that courts imposed a peace bond to keep them from hurting each other. Stories like this about the psychological differences of conjoined twins fascinated psychologists because they tested the boundaries of personhood by challenging fundamental notions of personality (Pingree 104). Two beings trapped in a single body, each retaining separate opinions, desires, and motivations, fundamentally struck at the core of people's sense of individuality.

Third, conjoined twins have been fusion monsters for religious officials because they violate the boundaries of spiritual personhood. Conjoined twins challenged notions of ontological individuality, forcing Christian leaders to consider if those who shared a body also shared a soul. For example, Lazarus and Joannes Baptista Colloredo were born in 1617 in Genoa, Italy with the latter's apparently inanimate torso growing out of the former's chest. Both were baptized, but this sacramental act did not prevent the Athenian Mercury from asking, "How will the 'Two brothers' arise at the day of judgment?" (qtd. Pender 161). Ultimately, these twins who seemed to combine multiple souls into a single body posed questions theologians found unanswerable. 


\section{Tragic Mulatto Fusion Monsters}

While scientists, psychologists, and theologians have treated conjoined twins like fusion monsters because they violate biological, psychological, and ontological boundaries on a personal level, American literature has regarded the tragic mulatto as a fusion monster that does the same on a racial one.

Since the colonial era, American legal, scientific, and sociological discourses claimed that blacks and whites were biologically different, articulating those differences most eloquently in the metaphor of "blood." In "Representing Miscegenation Law," Eva Saks notes American writers questioned or defended the supposedly biological differences between whites and blacks and found no better way to carry out such interrogations than with the figure of the tragic mulatto, carrier of both black and white blood. In his analysis of such literature, Sollors claims that because tragic mulattoes housed two races in a single body, their "conflict was ultimately believed to be biological, generated by the "warring blood' that was believed to be coursing in their veins" (224). This idea of "warring blood" appears repeatedly in American texts featuring mulattoes. Their white blood propels them to do one thing while their black blood drives them to do another, hurling biracial characters back and forth until their warring blood tears them apart and thrusts them towards tragic ends. For example, in William Faulkner's Light in August, the mixed-race Joe Christmas's schizophrenic behavior is explained in psycho-racial terms. A torrent of contradictory voices rage through his mind all because of the war between his black blood and white blood: "But his blood would not be quiet, let him save it. . the black blood drove him first to the negro cabin. And then the white blood drove him out of there, as it was the black blood which snatched up the pistol and the white blood which would not let him fire it" (449). In an American society that assumed whites and blacks were biologically different, the tragic mulatto became a fusion monster that combined bloodlines with tumultuous results.

American discourses also suggested tragic mulattoes were fusion monsters on psychological grounds. Mulatto fiction suggested that biracial characters contained two distinct minds, one black and one white. In Elizabeth Boatwright Coker's 1950 novel, Daughter of Strangers, Charlotte Le Jeune's "mixed river" of blood whirls in her brain, giving her a "troubled, uneasy frame of mind" and making her "a stranger to herself" (144). In this literary climate, blacks had one consciousness and whites had another. Sterling Brown noted this much in perhaps one of the most famous quotes from the study of mulatto literature where he notes that American writers used warring blood to explain the mixed race psyche. Through their works, the mulatto is "a victim of a divided inheritance; 
from his white blood come his intellectual strivings, his unwillingness to be a slave; from his Negro blood come his baser emotional urges, his indolence, his savagery" (160-161). Presumably, white blood made one intellectual while black blood made one emotional, and the black-white multiracial posed a challenge to racial thinking. Here, the mulatto is not just racially divided; he is also psychologically self-divided.

Thirdly, tragic mulatto fusion monsters ontologically unite races. American writers have represented these problematic beings as owners of a split soul. For example, in Richard Hildreth's 1852 abolitionist novel, The White Slave, the mulatto protagonist, Archy Moore, declares that from his black mother he inherits the soul of a slave, but from his white father he inherits a "proud spirit" (7). Here, Moore's conflict is not simply a social, familial, or personal one-it is a struggle cast in spiritual light. Penelope Bullock notes that this example is one of many. In her seminal essay, "The Treatment of the Mulatto in American Fiction from 1826-1902," she claims that in tales of the tragic mulatto, the spirit of his black mother compels him towards servitude while the spirit of his white father compels him towards rebellion (50-51). The tragic mulatto's white soul wars with its black one, paralyzing him with spiritual conflict. Nancy Tischler claims this struggle resembles a theological one where "the black blood and the white blood stage a gory civil war in the mind and body of the mulatto, much as the medieval writer would have had the Body and the Soul battling it out over possession of Everyman" (97). In this way, the tragic mulatto has resembled a fusion monster in an ontological sense. Like a possessed child or a conjoined twin, they have also been represented as housing multiple spirits in a single body.

\section{The Conjoined Twin, Tragic Mulatto Fusion Monster in THE THING WITH TWO HEADS}

While discourses on conjoined twins and tragic mulattoes have both suggested these groups are fusion monsters on physical, psychological, and ontological grounds, the monster in The Thing with Two Heads combines both of these kinds of fusion monsters. On one hand, like the conjoined twin, the film's "monster" violates the notion of personal identity, merging the bodies, minds, and souls of two individuals. On the other hand, like the tragic mulatto, this monster disrupts the concept of racial identity by blending the physical, psychological, and ontological characteristics of supposedly different races into a single body.

The first way the film's monster blends these categories is physically, coalescing two people into a single body. The film establishes Moss' body, enormous and fit, as one spatio-temporally discrete entity and Dr. Kirshner's body, crippled and ailing, as another. The narrative continually stresses the physical differences between these bodies. Dr. 
Kirshner's weakness dominates the film's beginning. He uses a wheelchair, is carted from one place to another by a chauffeur, and is even unable to perform surgery at the institution that bears his name. Conversely, the film emphasizes Moss' strength. When he first appears walking to the electric chair, he is shown to tower over the guards, officers, and warden who escort him to his death. An inmate yells for him to fight, make them work to kill him. This exhortation accentuates Moss' physical superiority over everyone else in the film, inviting viewers to recognize just how hard orderlies would have to work to kill him if he put up a fight. Once the bodies are fused, Dr. Kirshner contrasts his new body with his old one. As he stretches Moss' fingers and breathes through his lungs, Dr. Kirshner remarks about its strength, power, and vitality. In this regard, the film spends a majority of its first act contrasting the weakness of Kirshner's body with the strength of Moss' before spending the second act stressing their monstrous physical fusion.

As the film transgresses physical differences between individuals, it establishes physical differences between black and white. In a complex relay between collusion and re-appropriation, the film simultaneously perpetuates and mocks racial stereotypes. For example, the physical differences between the two races housed in this body even erupt over something as seemingly insignificant as food. Once Moss, Kirshner, and Williams hide in Lila's apartment, they consider a plan to prove Moss' innocence over a plate of pork chops. Facing the fried food, Kirshner recoils, dismissing it as junk food for the black underclasses. He further racializes his disdain by evoking racial stereotypes when he sneers, "What do you have for dessert? Watermelon?" In this context, the stomach becomes a battleground and the two heads feud over which kinds of racialized food it will digest. Moss continues to eat the pork, declaring his ownership over the body: "It's my stomach!" But Kirshner rebels, spoiling the dinner by puffing a cigarette that forces Moss to belch smoke mid-bite.

Featured on trailers, promotional posters, and publicity ads, this scene of the white head inhaling smoke that the black head exhales becomes one of the film's central showpieces where the thing with two head's physical self-division becomes most ridiculous. At the same time, however, it also becomes one of the moments that best articulate the film's "warring blood" comedy. The film spends great lengths of screen time to explain that Kirshner is able to successfully transplant organs where others fail because of his revolutionary heart-lung machines that filter blood among both bodies long enough to unite them. In these transplants, blood comes from separate individuals, each prone to infection, waiting to reject the other. In this particular two-headed transplant, however, blood also comes from separate races, each prone to different 
appetites, opposed preferences, and conflicting dispositions. The thing with two heads fuses the opposed characteristics of two human blood groups, type $\mathrm{AB}$ vs. type $\mathrm{O}$, but also the stereotypically opposed characteristics of two racial blood groups, blacks who eat soul food and whites who do not. Like conjoined twins, the thing with two heads must reconcile physical differences between one weak body and one strong one, but, like the tragic mulatto, it must also supposedly reconcile racial differences inherited through warring blood.

The fusion monster in The Thing with Two Heads also combines multiple minds into a single body. On one hand, the monster fuses the psyches of two individuals. Moss' central motivation is to prove his innocence, but this valid pursuit never trumps his compassion. He remains concerned about the wellbeing of Lila as well as Dr. Williams, not to mention the bystanders who flee from him in horror. During the motorcycle chase, he places himself in danger to keep other motorcyclists safe. As bigoted officers hurl racial insults at him, he still risks capture and death to disable squad cars without injuring any officers. After the surgery that finally amputates Kirshner's head, even after all the bigoted surgeon's abuse and threats, Moss and Dr. Williams do not kill him. Conversely, Dr. Kirshner's psychological motivation is to dominate his new body. He is ruthlessly selfish, advertising for a body donor without fully explaining the transplant procedure, deceiving unknowing people into forfeiting both their bodies and their lives. If he finds a participant, he plans to take control of the body and kill the donor simply so his "genius" may live on. Once he actually receives a participant who just happens to be African American, his gratefulness does not surpass his bigotry. Rather than appreciating his second chance at life, he spends his time insulting Moss, Lila, and Dr. Williams - the very people who hold his life in their hands. With the sympathetic Moss on one hand and the selfish Dr. Kirshner on the other, the film clearly establishes the thing with two heads as a fusion monster that combines two distinct psychological entities.

At the same time, the film racializes this psychological fusion with stereotypes. It establishes the black mind as sexual and the white mind as intellectual before fusing these opposed psychologies into one body. After dinner at Lila's house where both heads have vied for physical control over their shared anatomy, they retire to the bedroom. As Lila tucks him in, Moss tries to woo her into bed. She pulls away, explaining that she can't get over the two-headed monster he has become. Aroused and persisting, Moss offers to cover Kirshner's head with a pillowcase to which the white head snarls, "Is that all you people ever think about?" With this statement, the use of the essentializing phrase "you people," Kirshner racializes the situation, suggesting that sexual motivation is 
something essential to the black mind. Moss seems to validate this stereotype when he declares to Kirshner at this moment, only after Kirshner's head denies him access to sex, "Now, you know you have to go!"

If, as this scene suggests, the film casts sex as the primary motivation of black psychology, how does it racially code white psychology? Interestingly, it is right after this moment, when black masculinity has exerted its sexual power, that Kirshner begins to take control of his new body. After threatening Kirshner in order to keep sexual access to Lila, Moss falls asleep. As Moss snores away exhausted by sexual frustration, Kirshner concentrates his psychological energies, finally making fists with both hands. As he exercises mental power over this physical body, he smiles maniacally. If this scene suggests that African Americans are preoccupied with sex, this moment suggests that whites are preoccupied with domination. Moss seeks physical intimacy with a lover he has not seen for years while Kirshner wishes to control the body so he can kill Moss.

Like the dinner scene, this bedroom scene features prominently in the film's publicity campaign and for obvious reasons. Its overt sexuality functions like a cheap selling point to the young exploitation crowd to which it was marketed. At the same time, the scene hints at the sexual complexity that the two-headed monster presents. What is physical intimacy between two lovers when one has a head grafted onto his shoulders? To accept Moss' invitation, would Lila be consummating her relationship with him alone or with Kirshner as well? Titillation and allusions to ménage-a-trois aside, this bedroom scene is also central to the film because it ludicrously articulates the thing with two head's psychological self-division in racial terms. This fusion monster inherits two blood types but also two different racialized psychologies; its black half pursues sexual pleasure and its white half pursues mental control. Like conjoined twins, this fusion monster must reconcile psychological differences between individuals, a sexual Moss and an intellectual Kirshner. On the other hand, like tragic mulattoes, this fusion monster must also reconcile supposedly psychological differences between races, a lascivious black and an ascetic white.

Thirdly, the thing with two heads combines multiple souls into one body. Kirshner convinces Dr. Desmond (Roger Perry) to perform the two-headed transplant, claiming, "My genius must be prolonged. I want to transplant my head on a healthy body." When Kirshner pleads, "My genius must be allowed to continue. ...There is no other way for me to live," he evokes a form of Western dualism that conflates the anatomical brain with the soul to suggest that his metaphysical being can survive as long as his head does, even if it is transplanted upon another body. With this plea, the doctor suggests that there is some aspect of identity that 
transcends the physical, that something of him endures even after the body has gone. His quest to appropriate a new body is based on that assumption, the belief that his genius constitutes his true identity, that his soul will outlive the death of his anatomy.

Like conjoined twins, the fusion monster of The Thing with Two Heads houses two souls in a single body, but, like tragic mulattoes, those souls are also racialized. On three separate occasions, Kirshner uses that signature address of racist essentialism, "you people," an insultingly reductive statement that suggests there is such a thing as a black soul exclusive and essential to all black people. But essentialism is not only the tool of oppression. In her oft-cited consideration of "strategic essentialism," Gayatri Chakravorty Spivak claims that oppressed groups often make "a strategic use of positivist essentialism in a scrupulously visible political interest" that actually undermines oppression (214). For example, Dr. Kirshner tries to dismiss the individuality of African American people by clumping them into one racialized monolith, but African American characters insist on their unity by bonding through racial commonality. Upon originally escaping, when Moss first takes Dr. Williams, the only black member of the Kirshner Institute, hostage, he hails him with that signature phrase of anti-racist strategic essentialism, "soul brother," a unif ying title that mobilizes blacks to share a spiritual connection against white supremacy. For the bigot, the fear becomes that when he transplanted his head onto a black body, he may have turned his genius black. According to his own logic, he may be one of the souls to which he refers when saying, "You people."

Lila exploits this fear in the dinner scene. When Kirshner gags from eating collard greens, she mocks the blackening of his soul. Using his own racial stereotypes against him, she includes him in the "y'all" when she asks, "What do y'all think about having fried possum and chitterlings for supper tomorrow?" She includes him in the "we" when she says, "And after supper, we can all sit around and sing spirituals." As noted above, American literature has used the discourse of racialized souls to argue that a black spirit dooms one to servitude while a white spirit entitles another to rule. Kirshner benefits from this assumption, suggesting all blacks, all the "you people," share a spiritual disposition towards subservience, but when blacks evoke strategic essentialism-refer to each other as soul brothers, call their cuisine soul food, evoke Negro spirituals, and claim that blacks are spiritually connected in the struggle against white supremacy - the doctor becomes trapped by his essentialist assumptions. The discourse from which he benefited now ensnares him and forces him to fear that as he inhabits a black body he may also have a black soul. 
While the above may show how historical discourses on conjoined twins and tragic mulattoes meet in The Thing with Two Heads, questions about the film's significance may remain. To consider the film's full import, we must consider the extent to which the most important aspect of fusion monsters is that they reveal something about society. Like all monsters, fusion ones can be read as social symbols, and they horrify audiences precisely because they strike at a group's core values.

In this regard, besides combining multiple biological, psychological, and ontological entities, fusion monsters combine multiple social entities. Such has been the case with discourses concerning conjoined twins. Throughout history, people have interpreted the conjoined twin as a social symbol: two persons struggling in one physical body symbolize two social groups struggling in one political body. During the seventeenth century, Englishmen claimed Lazarus and Joannes Colloredo, the Italian conjoined twins, symbolized Catholic England's struggle with Rome (Pender 157). During the Civil War, Americans claimed Chang and Eng symbolized the struggle between Northerners and Southerners (Pingree). From 17th century England to 19th century U.S., the internal struggle of conjoined twins has symbolized the internal struggles of nations.

Similarly, the internal struggles of fictional mulattoes were used to symbolize the struggle between American racial groups. In the first book-length study of the tragic mulatto, Berzon notes that this literary figure is taken "as the embodiment of social misunderstanding, of the dislocation of modern life, of the search for the father, of the suffering of all mankind, as the conscience of mankind" (80-81). Many writers and readers of American literature have regarded the tragic mulatto in this archetypal way, claiming that the black blood and white blood warring in the mulatto's body symbolized the black and white races warring in the American national body.

The fusion monster in The Thing with Two Heads can also be read as a social symbol that articulates the struggles between black and white social groups in the United States during the 1970s. For years before the film's release, the Civil Rights Movement sought to integrate blacks into white society, securing their equality as a minority among the majority, but by the year of the film's release the Black Power Movement had gained authority. Giving up on the hope that American society could ever treat blacks equally, nationalists sought to create a separate society. Some held a Manichean worldview, seeking to reaffirm the beauty of black culture by purging it of all white influence: blacks had internalized racism, and if they wished to rise, they had to cleanse themselves of white thinking. ${ }^{2}$ The film articulates this desire to "get the man off your

2 For an excellent discussion of the dualistic roots of the Black Power Movement see Cornel West's "Malcolm X and Black Rage." 
back" by literally attaching a bigoted white head, the mind spouting racist ideology, onto the back of the black body that has internalized it. From the beginning, Moss rebels against the white head's domination. Upon waking from the surgery, he notices Kirshner attached to him, and when the doctor tells him "We are joined together temporarily," Moss grows enraged, thrashing about until doctors anesthetize him. Kirshner immediately regrets trying to dominate the black man, saying, "How am I ever going to control him. . .he could kill me!" Similarly, during the time of the film's release, whites began to see their control over blacks waning and the emergence of a Black Power Movement that threatened to consume them. Riots of previous years weighed heavy and fresh on the minds of many Americans, proof that the reconciliation offered by the Civil Rights Movement had given way to violent forms of black rage. In this way, this fusion monster, with all of its physical struggles between Moss and Kirshner, symbolized national struggles between blacks and whites.

While the conjoined twin/tragic mulatto fusion monster in The Thing with Two Heads symbolizes the struggles between black and white social groups as monstrous, it also symbolizes the necessity of that monstrosity, suggesting a kind of symbiotic relationship between white and black. After the initial surgery that fuses their bodies, Moss and Kirshner suffer an infection. Dr. Desmond, the operating surgeon, instructs assisting doctors to preserve the black head because they "need all the help [they] can get from him." Here, Dr. Kirshner's genius depends upon Moss's anatomy, and white genius relies on the black body. Conversely, in the film, this monster's black body also needs the white mind. During the getaway scene, Moss decides to shoot Kirshner's head, but Dr. Williams jumps in, declaring, "You kill him, you kill yourself!" This long after the transplant, the black body and the white head have fused and their lives inextricably depend upon each other. With this image of Moss and Kirshner assimilating into one physical body, the film suggests the need for blacks and whites to assimilate into one national body.

Despite these moments that suggest racial symbiosis, the film's ending ultimately symbolizes the relationship between these two groups as an antagonistic one that ends with eventual re-segregation. Despite scenes that emphasize racial hybridity, separation remains the central motivation of the Moss/Kirshner monster. Throughout their escape, both heads vie for Dr. Williams's assistance. Kirshner offers him an executive position at the institute if he will cut off the black head. Kirshner explains that he still has much to teach the world about transplants, and if Williams helps him, he will help humanity. Conversely, Moss spends the entire film asserting that he is innocent, does not deserve execution, and, therefore, Kirshner has no right to his donated body. Appealing to 
Dr. Williams's morality, Moss claims that if he was guilty, he would die willingly, but since he killed no one, he should have a chance to clear his name, a chance Williams must facilitate by amputating Kirshner's head so Moss can live.

In the end, Moss wins Dr. Williams's sympathy. To save the convict's life, the doctor decides to remove Kirshner's head, but as the group breaks into a surgical supply warehouse to retrieve necessary medical instruments, Kirshner finally takes full control of Moss's body and beats the two black men unconscious before retreating to his private laboratory. There, he makes preparations to amputate the black head himself, but just as the scalpel reaches Moss's neck, Dr. Williams bursts in, snatches the blade away, and declares, "You wouldn't want to do that, doctor. You'd be killing an innocent man." The camera cuts away and moments later, Dr. Williams appears on the phone calling Dr. Desmond, telling him to hurry to Dr. Kirshner's house. Dr. Desmond rushes into the room only to find Dr. Kirshner's disembodied head attached to a heart-lung, blood-filtering machine, moaning, "Get me another body, please." While the film suggests that this fusion monster needs both black and white heads, its ending, suggests that amputation is inevitable.

Furthermore, when the credits roll over images of Moss, Lela, and Dr. Williams driving away together smiling, clapping, and singing "Oh Happy Day," the conventions of cinematic formal closure invite the audience to celebrate the amputation of the white head from the black body. Given this conclusion, the conjoined twin/tragic mulatto in The Thing with Two Heads symbolizes the antagonism between blacks and whites that only seems to end with the eradication of fusion, the re-individuation of Moss and Kirshner, and the re-segregation of blacks and whites.

The Thing with Two Heads flirts with the idea of racial hybridity, spends a majority of its length exploiting the horror of the conjoined twin/tragic mulatto, but, in the end, the hybridity this fusion monster symbolizes is dismissed. Among the film's endless comedic gags, the only thing meant to be taken seriously may be the desire of the monster's two halves to amputate the other, to re-individuate themselves, and, symbolically, to re-segregate black and white. As Moss eventually wins sole ownership over his body, the film implies that African Americans can break free from white supremacy and amputate the oppressive whiteness that has been grafted upon them. As Dr. Kirshner ends up a disembodied head pleading for another body, the film suggests that whiteness is predatory, a disembodied genius always preying on the bodies of others. In the end, the film suggests that black and white are essentially incompatible essences.

At the same time, The Thing with Two Heads mocks essentialist assumptions that blacks and whites are biologically, psychologically, and 
ontologically different. The fact that the film was marketed as a horror film suggests that the blurring of the categorical distinctions between blacks and whites is horrific, but the fact that the film functions more like a comedy suggests that this transgression of racial distinctions is also pleasurable. Given how the film treats the conjoined twin/tragic mulatto with such humor, one has to wonder whether its fusion monster is a monster at all. If, as Carroll claims, fusion monsters horrify because they transgress conceptual binaries and contemporary categories increasingly embrace hybrid attributes, then one has to wonder if fusion monsters still horrify. Throughout history, conjoined twins horrified because they united categorically distinct biological, psychological, and ontological attributes that would otherwise individuate people, but in the 21 st century where categorical distinction increasingly erodes into hybridity, are conjoined twins still monsters? Throughout American literature, tragic mulattoes horrified because they united categorically distinct physical, mental, and spiritual attributes that would otherwise individuate races, but in the 21 st century, are mulattoes still monstrous?

Conjoined twins, mulattoes, and all kinds of fusion monsters might not horrify as much as times past. Carroll's model of monstrosity relies heavily on dichotomous thinking that may have faded slightly. The Thing with Two Heads suggests this much because its tone does not resemble that of a conventional horror film. Traditionally, such films employ dark shadows, ominous music, and disturbing monsters to horrify audiences, but The Thing with Two Heads features natural daylight, upbeat music, and a "monster" that cracks jokes, smiles, and never poses a real physical threat to any positive human characters. Given these facts, the film employs horror less than what Brophy calls "horrality," an amalgamation of horror and hilarity. He claims that after decades of cliché conventions horror films no longer frighten audiences with suspense. Instead, these movies seek to disgust and titillate viewers by destroying bodies with "a perverse sense of humour" (276). Likewise, Frost's "horror" film seems less interested in frightening audiences than using perverse humor to destroy the individual racial body. In the past, conjoined twins may have horrified because they undermined categorical distinctions necessary for concepts of personal selfhood, and tragic mulattoes may have horrified because they undermined distinctions necessary for concepts of racial identity. Both the conjoined twin and tragic mulatto horrified because they assaulted audiences' sense of themselves. Given The Thing with Two Heads' humorous tone, however, one must consider that the fusion monster pleases audiences. Given how this film utilizes horrality rather than horror, one must consider that audiences do not fear as much as invite the conjoined twin/tragic mulatto's assault against their personal and racial selfhood. 
With the way that it presents these challenges-exposing racial stereotypes to challenge them and reveling in a transracial body-The Thing with Two Heads works as a unique text of tragic mulatto literature. Traditionally, this literary genre has confronted racial, social, and religious themes with a serious tone, using multiracial characters to make political arguments within the realms of realistic plausibility. This horralious film, however, offers a different way to confront these issues, a tone that addresses these social issues with horror and comedy, evoking stereotypes of the tragic mulatto and bending the laws of reality to mock American assumptions about race. For these reasons, The Thing with Two Heads should be plucked from obscurity, the confines of the Blaxploitation horror niche, and the shelves of B-movie aficionados to be taken for what it is: a text that, like The House Behind the Cedars, The Autobiography of an Ex-Colored Man, and Passing, can offer valuable observations about American racial discourse but, unlike those novels, can use the ridiculous conventions of horror and humor to strike at the truth in ways serious texts cannot.

\section{Works Cited}

Benshoff, Harry M. "Blaxploitation Horror Films: Generic Reappropriation or Reinscription?" Cinema Journal 39.2 (Winter 2000): 3150 .

Berzon, Judith R. Neither White Nor Black: The Mulatto Character in American Fiction. New York: New York UP, 1978.

Brophy, Philip. "Horrality-The Textuality of Contemporary Horror Films." The Horror Reader. Ed. Ken Gelder. New York: Routledge, 2000. 276-284.

Brown, Sterling. "Negro Character as Seen by White Authors." Dark Symphony: Negro Literature in America. Eds. James A. Emanuel and Theodore L. Gross. New York: Free Press, 1968. 139-171.

Bullock, Penelope. "The Treatment of the Mulatto in American Fiction from 1826-1902." Master's thesis. Atlanta U, 1944.

Carroll, Noël. The Philosophy of Horror or Paradoxes of the Heart. New York: Routledge, 1990.

Carter, Gregory T. "From Blaxploitation to Mixploitation: Mixed-Race, Male Leads and Changing Black Identities." Mixed Race Hollywood. Eds. Mary C. Beltrán and Camilla Fojas. New York, NY: New York UP, 2008.

Coker, Elizabeth Boatwright. Daughter of Strangers. New York: E.P. Dutton, 1950. 
DeSouza, Carole. "Against Erasure: The Multiracial Voice in Cherrie Moraga's Loving in the War Years," in Mixing It Up: Multiracial Subjects. Ed. SanSan Kwan and Kenneth Speirs. Austin: U of Texas P, 2004. 181-206.

Faulkner, William. Light in August. New York: Vintage International Edition, 1990.

Fiedler, Leslie. Freaks: Myths and Images of the Secret Self. New York: Simon \& Schuster, 1978.

Frost, Lee, dir. The Thing with Two Heads. American International Pictures, 1972. Film.

Hildreth, Richard. The White Slave: Another Picture of Slave Life in America. Leicester: Herbert J. Spencer, 1929.

Paré, Ambroise. On Monsters and Marvels. Trans. Janis L. Pallister. Chicago: U of Chicago P, 1982. (1573).

Pender, Stephen. “'No Monsters at the Resurrection': Inside Some Conjoined Twins." Monster Theory: Reading Culture. Ed. Jeffrey Jerome Cohen. Minneapolis: U of Minnesota P, 1996. 143-167.

Pingree, Allison. “America's 'United Siamese Brothers': Chang and Eng and Nineteenth-Century Ideologies of Democracy and Domesticity." Monster Theory: Reading Culture, Ed. Jeffrey Jerome Cohen. Minneapolis: U of Minnesota P, 1996. 92-114.

Saks, Eva. "Representing Miscegenation Law." Interracialism: BlackWhite Intermarriage in American History, Literature, and Law. Ed. Werner Sollors. New York: Oxford UP, 2000. 61-81.

Sollors, Werner. Neither Black Nor White Yet Both: Thematic Explorations of Interracial Literature. Cambridge, MA: Harvard UP, 1997.

Spivak, Gayatri Chakravorty. "Subaltern Studies: Deconstructing Historiography." The Spivak Reader. Eds. Donna Landry and Gerald MacLean. New York: Routledge, 1996. 203-236.

Tischler, Nancy. Black Masks: Negro Characters in Modern Southern Fiction. University Park: Pennsylvania State UP, 1969.

West, Cornel. Race Matters. "Malcolm X and Black Rage." Boston: Beacon, 1993. 93-106.

Wood, Robin. "An Introduction to the American Horror Film." American Nightmare: Essays on the Horror Film. Eds. Robin Wood and Richard Lippe. Toronto: Festival of Festivals, 1979. 7-28. 